\title{
Influence of Family Factors on Student Mothers' Educational Participation in Public Secondary Schools in Baringo County, Kenya
}

\author{
Margaret Jepkemboi Ayub ${ }^{1, *}$, Thomas K. Ronoh ${ }^{2}$, Micah C. Chepchieng ${ }^{2}$, Teresa Njonge ${ }^{2}$ \\ ${ }^{1}$ Doctor of Philosophy Student in Educational Foundations, Egerton University, Kenya \\ ${ }^{2}$ Department of Psychology, Counselling and Educational Foundations, Faculty of Education and Community Studies, \\ Egerton University, Njoro, Kenya
}

Received July 26, 2020; Revised April 30, 2021; Accepted May 23, 2021

\begin{abstract}
Cite This Paper in the following Citation Styles
(a): [1] Margaret Jepkemboi Ayub, Thomas K. Ronoh, Micah C. Chepchieng, Teresa Njonge, "Influence of Family Factors on Student Mothers' Educational Participation in Public Secondary Schools in Baringo County, Kenya," Universal Journal of Educational Research, Vol. 9, No. 6, pp. 1298-1305, 2021. DOI: 10.13189/ujer.2021.090619.
\end{abstract}

(b): Margaret Jepkemboi Ayub, Thomas K. Ronoh, Micah C. Chepchieng, Teresa Njonge (2021). Influence of Family Factors on Student Mothers' Educational Participation in Public Secondary Schools in Baringo County, Kenya. Universal Journal of Educational Research, 9(6), 1298-1305. DOI: 10.13189/ujer.2021.090619.

Copyright $\bigcirc 2021$ by authors, all rights reserved. Authors agree that this article remains permanently open access under the terms of the Creative Commons Attribution License 4.0 International License

\begin{abstract}
Secondary level of education has been reviewed as a fundamental stage for education progression where learners acquire basic skills in their future areas of specialization. At this level, students participate in educational activities that pertain to secondary school education. However, in Baringo County there is high prevalence of teenage pregnancies due to high poverty levels, high illiteracy rates among parents and retrogressive cultural beliefs that may have influenced the educational participation of student mothers. The purpose of the study was therefore to establish the influence of family factors on educational participation of student mothers in public secondary schools in Baringo County, Kenya. This study was ex-post facto in approach and utilized correlational research design. The target population for the study was 1277 student mothers. The sample size of the student mothers in this study was 296 and was selected using stratified random sampling. The study collected data from student mothers using questionnaires. Validity of the questionnaires was ascertained through developing the research instruments in line with the research objectives and also consulting the supervisors and lecturers in educational foundations. A pilot study was done among 30 student mothers to ascertain the reliability of the questionnaires. Based on the pilot data, the Cronbach's alpha coefficient for the family factors questionnaires was
\end{abstract}

0.870 and 0.885 for educational participation. The data was analysed using SPSS version 24 . The study found that there was a significant relationship between family factors and educational participation of student mothers in secondary schools in Baringo County at 5\% significance level. The study concluded that family factors significantly influenced educational participation of student mothers. The study findings would benefit many educational stakeholders, policymakers, and scholars in increasing the educational participation of student mothers through enhanced family support.

Keywords Educational Participation, Family Factors, Student Mothers

\section{Introduction}

\subsection{Background of the Study}

Different scholars, organizations and institutions in diverse contexts have highlighted the importance of secondary education [1]-[4]. Secondary level of education has been seen as a fundamental stage for education progression where learners acquire basic skills for their 
future areas of specialization [5]. It is also on this stage where leaners' get to identify their areas of interest for post-secondary education studies [6]. Secondary education determines the social class as well as the position of individuals in the society [7]. With secondary level of education, individuals can gain entry to labour market or even proceed with post-secondary education such as gaining entry to colleges, Technical and Vocational Education and Training (TVET), and universities amongst others [1].

At the secondary level, students are expected to participate in educational activities that pertain secondary school education [8]. Educational participation can be defined as involvement in important aspects of schooling activities [9]. These activities may include students' leadership roles, membership and participation in honour societies and service clubs, music, sports, academic debates and academic competitions and occasionally, the students might be required to contribute to literary publications such as newspaper articles and magazines [10]. Active participation in educational activities in secondary school lead to more learning and development of important skills, acquisition of knowledge and education, enhanced well-being, increase in self-confidence, self-esteem and self-belief of the learner [11]-[13]. To participate in most of the educational activities in secondary level of education it requires motivation and self-dedication [14].

All students at the secondary level of education are presumed to be minors, single, without children and unaccompanied by dependents. However, due to teenage pregnancies, cases of student mothers in secondary schools are becoming an increasing problem [15]-[17]. According to [18] approximately14-15 million teenage girls and young women become mothers every year and this accounts for more than $10 \%$ of births worldwide. Majority of the student mothers in secondary schools are aged between 14 and 19 years and are not yet married. Despite a high degree of participation in school activities reported as essential for learning, student mothers face diverse challenges that may not allow them to participate in some educational activities in the secondary schools [19][20][21].

According to [22] social expectations are that their motherhood status is incompatible with being in school and are therefore often pushed-out, denied admission or they themselves self-select out of school. The student mothers tend to have overload of domestic chores and child-care roles, besides undertaking intensely high-pressure demands of academic work [23]. A student mother is expected to be a good mother to her child and at the same time is expected to perform well in their academic endeavours. Striking a balance in the dual roles becomes a challenge to the student mothers and some of them drop out of school to concentrate in motherhood roles [20]. High dropout cases of teens from secondary schools have contributed to high gender inequality in education [24]. In the United States, [5] has indicated that while up to $25 \%$ of teen mothers who drop out of senior high schools later return to school to further their studies, nearly half of them failing to complete their senior high education. Yunas [26] recommend that every segment of the student population should have the same opportunity to participate in all aspects of the educational experience. Despite this recommendation, student mothers are often marginalized and thwarted in their educational endeavours as shown in a study in Kenya and in the United States of America [16], [25].

High prevalence of child bearing and child rearing among secondary school going girls across the globe has caused several countries and organizations to have developed intervention strategies aimed at keeping student mothers at school [9][26][27][28]. For example, global and multilateral institutions such as UNICEF, UNESCO, World Bank, and Forum for African Women Educationalists (FAWE) have championed responses for supporting gender equity in education [5]. In the United States of America, school going mothers are protected by Educational Amendments Act of 1972. This Act protects the student mothers from discrimination of any kind and also creates avenues to cater for the unique needs of student mothers [29]. In the United Kingdom, the Equity Act of 2010 protects school going mothers from any form of discrimination, either on gender or on motherhood [30].

In African context, several Return-to-School Policies have been instituted to bridge the gap in education access to student mothers. For example, in Sub-Saharan countries such as Cameroon, Madagascar, Namibia, Botswana, South Africa, Zambia and Kenya among others, Forum for African Women Educationalists (FAWE) have been in the forefront in advocating for Education For All (EFA) [31]. Young mothers have been a major focus for the FAWE and have been offering scholarships to at least $10 \%$ of the student mothers returnee to schools each year in the Sub-Saharan countries [31]. The government of Zambia has also been advocating for returning to school policy for student mothers at secondary and primary level of education. This effort has been seen to yield fruit with $60-80 \%$ of the Zambian teenage mothers returning to schools [32]. In Zimbabwe, P35 Policy of the Ministry of Education, Arts and Culture allow pregnant school girls maternity leave to deliver the baby and come back to school [33]. In cases where a school boy is responsible for the pregnancy, he is also allowed paternity leave and comes back to school at the same time the girl comes back [33].

In Kenya, Return to School Policy was established in 1994. This policy provides avenues to help student mothers to go back to school even after giving birth in order to continue their studies [16]. This is a wider view to facilitate the education of girl child in Kenya. The National School Health Policy passed in 2009 articulates the actions that school administrators should follow in re-admitting student mothers back to school [34]. National Women's Law 
Center in Kenya also provides guidelines on dealing with student mothers in both primary and secondary level of education [35]. The Center is composed of advocates, experts, and lawyers who fight for gender justice and taking on issues that are central to the lives of women and girls. National Women's Law Center participates in public policy making, and in our society, especially for women and girls facing multiple forms of discrimination. The Center recommends that student mothers be allowed to continue their studies as long as they wish [35]. In addition, the National Education Sector Plan (NESP) released in 2014, has taken into consideration the challenges of student mothers in Kenya. The plan provides for support systems to encourage educational participation of student mothers in secondary schools in Kenya. The support systems include provision of guidance and counselling services for all students, provision of conducive learning environment for students and assurance of students' safety among others [36].

Despite these support systems, there are diverse challenges that limit the educational participation of student mothers in Kenyan secondary school and specifically Baringo County. In Baringo County, more than a quarter $(27 \%)$ of the population are adolescents aged 10-19. According to Baringo County Director of Education, about one in ten girls aged 15-19 years in Baringo County have begun childbearing against one in 18 girls in the same age bracket at national level. Specifically, $2.7 \%$ are pregnant with their first child and $10.5 \%$ have ever given birth. According to the Ministry of Health in Kenya in 2015, Baringo County's age specific fertility rate for girls aged 15-19 (adolescent birth rate) was 76 births per 1000 girls. Kurgat [37] indicated that $55.6 \%$ of head teachers encouraged girls who had dropped out of school due to pregnancy to return to school. However, this study by [37] did not establish whether the students returned to school and also whether they participated in the educational activities in the school. Could there be factors influencing the educational participation of student mothers in public secondary schools in Baringo County of Kenya?

\subsection{Statement of the Problem}

According to Baringo County Director of Education in 2017, in Baringo County, especially in Mogotio and Tiaty Sub counties there is high prevalence of teenage pregnancies with about one in ten girls aged 15-19 years having begun childbearing against one in 18 girls in the same age bracket at national level. This could be due to high poverty levels, high illiteracy rates among parents and retrogressive cultural beliefs that could influence student mothers' participation in educational activities in diverse ways and therefore warrants an inquiry. This has led to many school dropout cases despite high degree of participation in school activities reported as essential for learning. The few studies previously conducted in Baringo
County on student mothers have only established prevalence of teen pregnancies and re-entry of student mothers back to secondary school. There is no conclusive study done in Baringo County to establish the influence of family factors on educational participation of student mothers in public secondary schools in Baringo County, which created a research gap.

\subsection{Objective of the Study}

To determine the influence of family factors on student mothers' educational participation in public secondary schools in Baringo County, Kenya.

\subsection{Research Hypothesis}

$\mathrm{H}_{01}$ There is no statistically significant influence of family factors on student mothers' educational participation in public secondary schools in Baringo County, Kenya.

\section{Family Factors and Student Mothers' Educational Participation}

A study by [47] showed that the partnership between family and school had a significant effect on educational achievement of students. Additionally, [48] noted that family characteristic such as their commitment to education of their children, their education level, and quality time with their children and knowledge on importance of education, influenced the educational achievement of their children. Therefore family factors have a key role to play in the student mothers' education participation levels. Family factors refer to household characteristic indicators such as type of family based on a number of adult members, income, occupation, parental education, home tasks, and family size [38]. It refers to family resources or stress factors that determine participation in educational activities by student mothers in the school [39]. Family size refers to the number of siblings, number of adults and number of extended kin while family structure refers to who the family members are and their relationship to each other in terms of marriage and parenthood structures affecting education activities of student mothers [40]. Examples include living situations of student mothers such as whether they are living independently, with a partner, or with extended members of the family in the same household at home [41].

In a study based on college student mothers in Samar State University in the Philippines, [42] examined the role of family factors amongst other factors on the student mothers' educational participation. The study used a qualitative research approach in which the data was collected using semi structured interviews. The study respondents were purposively picked from the student 
mothers within the university who were willing to participate in the study. In the context of the family support, [42] observed that student mothers who were supported by their own mothers were able to cope with the financial and moral demands of student motherhood. Their mothers' support with childcare enabled them to participate in education activities with relative peace of mind. While the study by [42] revealed the relationship between family factors and student mothers' education participation, the study was based in a university set up in Philippines. The study thus presented a contextual gap that this study sought to fill, as it examined the student mothers within secondary schools in Kenya. The contextual factors of student mothers in a university set up were different to those in a secondary institution.

In United States, [43] examined the negotiation of conflicting roles amongst the graduate student mothers. Similar to [42], [43] also used a qualitative research approach in which data was collected using semi structured in-depth interviews. The study used the snowball sampling method in identifying the graduate student mothers within Texas woman's university who were interested in participating in the study. The interviewed student mothers illustrated the manner in which family support was critical in their education journey. One respondent narrated that her mother offered to baby sit her child hence giving the student mother ample time to adequately pursue her university education. These results of the child support were consistent to those of [42] in a study in the Philippines. However, [43] noted that one respondent noted that her husband preferred her working to ease the financial pressure as opposed to getting a second masters' degree. She thus felt unsupported to the desired level that influenced her education progress at the university. Similar to [42] the study by [43] was based on student mothers within the context of a university setting in a developed country. The study thus presented a contextual gap as the current study was based on secondary school context in a developing country.

In the context of Ghana, [40] examined the challenges the student mothers were facing upon re-entry into the Ghana secondary schools. To achieve its objectives the study used qualitative research approach and snowball sampling method to identify target population members. Interviews were used to gather the information of the study. Baa-Poku [40] study observed various parental factors that influence educational participation of the student mothers. The study noted that some parents of the student mothers failed to pay school fees and discouraged their children from pursuing education, as it was perceived as waste of time. Some of the respondents also had to fend for themselves and their children. However, the study documented that two respondents narrated support given by their grandmother and mother respectively in child care enabling them to attend school. This observation of child care support for student mothers is consistent with those of
[42] and [43] in Philippines and United States of America respectively. However, this study being based in Ghana, which is culturally different country to Kenya, presented a contextual gap that this study sought to fill.

In a study in Zambia, [39] looked at the challenges of the re-entry policies for the teenage mothers after child birth within the context of primary schools. The study used a target population composed of girls who have been re-admitted, schoolteachers, and grades $9,8,7$ and 6 pupils in Ndola district. The study used purposive sampling method in data collection aspects. Data was collected through triangulation method in which questionnaires, in-depth interviews and focus group discussions were utilized. The study revealed reluctance among the pupils' parents to be involved in the re-entry of the teenage mothers at primary school in the implementation stage. This was attributed to low awareness levels amongst the parents on the re-entry policy and its provisions. Mudenda [39] recommended in their study on the need for the parents to be sensitized on the need for the girls to complete their education. The study by [39] focused on primary school students within Zambia. This study however contextually examined the student mothers within a secondary set up.

The role of the parents of the teenage mothers on the educational participation was also examined in South Africa. Chauke [44] study in South Africa focused on the secondary school in Hlanganani South Circuit. Using qualitative research design, the study revealed that student mothers received various kinds of support from their own mothers which enabled them to proceed with education aspects. The author further noted that most of the student mothers came from financially disadvantaged homes that cannot afford to hire house helps for the children. The study thus noted that in cases where the parents of the student mothers offered child care support it served to relieve the social, time and financial demands of child rearing from the teenage mothers. This was key in enabling these teenage mothers to concentrate on their education.

However, the study by [44] noted that in extremely financially disadvantaged homes, the teenage mothers sometimes had to baby sit their own children in cases where their own mothers and elder siblings had to fend for the family through short term work openings. These results by were also similar to those by [40] in Ghana that documented instances where there was lack of parental support either due to poverty or attitudinal factors from the parents. The study by [44] was based in South Africa and examined educational participation in the context of concentration on education matters only. The current study therefore conceptually differs from the current study, which examined the education participation in a broader context including co curriculum activities and socialization aspects within the schools.

In a study focusing on Vhembe district in South Africa, [33] examined the education achievement of teenage 
mothers in the secondary schools within the district. The study used mixed methodology approach with quantitative research approaches being utilized in the study. Data was thus collected from a target population of teen mothers at Vhembe District secondary schools in the Limpopo Province through questionnaires and interviews. The study documented contrasting views in respect to the parental support accorded to student mothers. One respondent documented being told to go to her boyfriend for the child needs maintenance. The financial needs of the child upkeep became a challenge leading to school drop out in favour of early marriage for the sake of the child. However, [33] noted that another respondent indicated parental support in respect to child upkeep that motivated them to work hard in school. The study by [33] examined the parental support and family support only within the context of financial support to the teenage mothers for the child upkeep. The study thus however failed to examine other aspects of family factors that influence education participation. The current study filled that gap.

Family support is a key component of the family factors influencing educational participation levels. In this context, [38] undertook a study in Bungoma amongst the primary schools in the county. The study sought to examine the influence of teenage motherhood on academic performance. The study used a mixed methodology. The study administered a semi-structured questionnaire to the head teachers and teenage mothers in public primary schools in the Chepkurkur sub location. The study revealed that the academic performance of the teenage mothers is dependent on how the parents of the teenage mothers supported them. Amongst the support that they were given included guidance and counselling on various life aspects, guidance of parenthood, and assistance with challenging academic task. While the study by [38] was undertaken in Kenya, the study was contextually different from the current study as it focused on primary school children within Bungoma County while the current study was based on secondary students within Baringo County. Additionally, the authors, focused on the academic performance of student mothers while the current study focused on their educational participation and therefore a conceptual research gap.

\section{Research Methodology}

This study was ex-post facto in approach, which utilized the correlational research design. The target population for the study was 1277 student mothers in public secondary schools in Baringo County. A multi-stage sampling technique was used to identify and select the participants. As a result, since the independent variables are multilevel in nature, the sample selection involved two main levels, that is, individual level (L1) and contextual level/group level (L2) comprising families, schools, communities. A sample size of 296 student mothers was arrived at based the determination of the sample size on a Cochran, 1977 formula. For the purpose of data triangulation and to supplement the data collection tools, the current study also interviewed 34 class teachers and 34 teacher counsellors.

The study used closed-ended questionnaires for data collection from student mothers. Validity of the questionnaires was ascertained through developing the research instruments in line with the research objectives and also consulting the supervisors and lecturers in educational foundations. A pilot study with 30 mothers was done to test the reliability of the questionnaires. Based on the pilot data, the Cronbach's alpha coefficient for the family factors was 0.870 and that of educational participation was 0.885 . The achieved reliability results for the current study implied that the study achieved the desired reliability threshold of 0.7 and therefore reliable for making generalization of the study findings. Data was analyzed using Statistical Package for Social Sciences (SPSS) version 24. Pearson correlation was used to establish the relationship between family factors and educational participation of student mothers while simple linear regression was used to test the hypothesis of the study.

\section{Results and Discussions}

The study established that $12.2 \%$ of the student mothers were in Form One, 25.7\% were in Form Two, 30.6\% were in Form Three and $31.6 \%$ were in Form Four. This is an indication that the prevalence of student motherhood increased with the increase in the level of education in secondary levels of education. The study further showed that majority of the student mothers were aged between 18 to 20 years $(46.4 \%)$, followed by those aged between $15-17$ years (41.9\%). Only $2.8 \%$ and $9.0 \%$ of the student mothers were aged between below 15 years and above 20 years, respectively. The ages of students in secondary schools in Kenya according to the Kenyan curriculum is between 14 years and 17 years [45] and therefore the majority of the student mothers aged above this range is probably due to the year(s) wasted in childrearing before resuming back to school.

The study performed Pearson correlations to establish the relationship that exists between family factors and educational participation of student mothers. Table 1 shows the relationship between the family factors and the educational participation of student mothers in secondary schools in Baringo County.

Table 1. Correlation between Family Factors and Educational Participation of Student Mothers

\begin{tabular}{lcc}
\hline & & Educational Participation \\
\hline & Pearson & $0.411^{* *}$ \\
Family & Correlation & 0.000 \\
Factors & Sig. (2-tailed) & 286 \\
& $\mathrm{~N}$ & 0 \\
\hline
\end{tabular}

Table 1 indicates that there was a moderate positive 
relationship between family factors and educational participation of student mothers in secondary schools in Baringo County. This is due to a correlation coefficient of 0.411 . In addition, the study established that the observed relationship between family factors and educational participation of student mothers was statistically significant at $5 \%$ significance level $(\mathrm{p}<0.05)$. This is due to a $p$-value of less than 0.05 . This implies that increase in family support increased the level of educational participation of student mothers and vice versa. A study by [46] also established that there was a positive relationship between family support and education participation of student mothers.

The study further sought to establish whether the educational participation of student mothers from secondary schools in Baringo County could be explained by the family factors of student mothers. Table 2 shows the model summary of a simple regression analysis between family factors and student mothers' educational participation.

Table 2. Model Summary for Family Factors and Educational Participation

\begin{tabular}{ccccc}
\hline Model & R & R Square & Adjusted R Square & $\begin{array}{c}\text { Std. Error of the } \\
\text { Estimate }\end{array}$ \\
\hline 1 & $0.411^{\mathrm{a}}$ & 0.169 & 0.166 & 0.72643 \\
& \\
\hline
\end{tabular}

The obtained R-value from the model was 0.411 , which implied that there was a moderate relationship between the observed and predicted values of educational participation. This is an indication that the model provides a good fit for the data. The achieved R-Square value of 0.169 implies that $16.9 \%$ of the variation in the educational participation of student mothers in secondary schools in Baringo County is due to observed variances in family factors from student mothers' families.

The adjusted R-Square Value indicates that on adding predictor variables to the regression model, the model would improve the regression predictability less than expected. This is because the Adjusted R-Squared is less than the R-Square Value. The model presented was found to be accurate in its prediction due to a standard error of estimate of less than 1.00 (standard error of estimate of 0.72643 ). The study further sought to establish whether the regression model had a statistically significant predictive power as a whole. This was established using the analysis of variance as shown in Table 3.

Table 3. ANOVA $^{\mathrm{a}}$ for Regression between Family Factors and Educational Participation

\begin{tabular}{ccccccc}
\hline \multicolumn{2}{c}{ Model } & $\begin{array}{c}\text { Sum of } \\
\text { Squares }\end{array}$ & df & $\begin{array}{c}\text { Mean } \\
\text { Square }\end{array}$ & F & Sig. \\
\hline \multirow{4}{*}{1} & Regression & 30.483 & 1 & 30.483 & 57.766 & $0.000^{\mathrm{b}}$ \\
& Residual & 149.865 & 284 & 0.528 & & \\
& Total & 180.348 & 285 & & & \\
\hline
\end{tabular}

a. Dependent Variable: Educational Participation b. Predictors: (Constant), Family Factors

Table 3 indicates that the regression model as a whole had statistically significant predictive power. This is because the observed F-Statistic value (57.766) was greater than the Critical F-Statistic value (3.892) from the F-Tables and $p$-value less than 0.05 . This implies that the regression model provides a good fit for the data than a model with no predictor variables and that the family factors are significant predictors of student mothers' educational participation. The study further investigated the sensitivity of the dependent variables to the changes in the independent variables using model coefficients as shown in Table 4.

Table 4. Model Coefficients for Regression between Family Factors and Educational Participation

\begin{tabular}{ccccccc}
\hline \multirow{2}{*}{ Model } & \multicolumn{2}{c}{$\begin{array}{c}\text { Unstandardized } \\
\text { Coefficients }\end{array}$} & \multicolumn{2}{c}{$\begin{array}{c}\text { Standardized } \\
\text { Coefficients }\end{array}$} & \multirow{2}{*}{ S } & Sig. \\
\cline { 2 - 5 } & B & Std. Error & Beta & & \\
\hline (Constant) & 2.343 & 0.145 & & 16.126 & 0.000 \\
Family Factors & 0.367 & 0.048 & 0.411 & 7.600 & 0.000 \\
\hline
\end{tabular}

Dependent Variable: Educational Participation

According to Table 4, there is a positive relationship between family factors and educational participation of student mothers in secondary schools in Baringo County as shown by beta coefficient of 0.367 . This relationship was found to be statistically significant due to p-value less than 0.05 . The relationship implies that a unit increase in family support results into 0.367 units increase in the level of educational participation of student mothers with other factors held constant. The first hypothesis of the study stated that there is no statistically significant influence of family factors on student mothers' educational participation in public secondary schools in Baringo County. This hypothesis was therefore rejected at 5\% significant level and the study established that there is statistically significant influence of family factors on student mothers' educational participation in public secondary schools in Baringo County. This finding is consistent with a study by [16], which established that family factors significantly predicted the level of educational participation of student mothers in secondary schools.

\section{Conclusions}

The study concluded that family factors significantly influenced student mothers' educational participation in public secondary schools in Baringo County. It was also noted that family factors significantly predicted student mothers' educational participation. Since the study established that student mothers were mostly involved in domestic chores such as cleaning, meal preparation that distract them from school activities, the study therefore recommends families of student mothers to exempt them 
from most of domestic chores to concentrate on their studies. The study further recommends families/parents to support the education of student mothers rather than prioritizing education of the other siblings or preferring student mothers working to ease the financial pressure of childcare as established in this study. Families may be sensitized in respect to this through the village elders, chiefs and other local administrators.

\section{REFERENCES}

[1] A. G. Anyieni and D. K. Areri, "Assessment of the Factors Influencing the Implementation of Strategic Plans in Secondary Schools in Kenya," J. Educ. Pract., vol. 7, no. 16, pp. 1-8, 2016.

[2] S. R. Psaki, K. J. McCarthy, and B. S. Mensch, "Measuring Gender Equality in Education: Lessons from Trends in 43 Countries," Popul. Dev. Rev., vol. 44, no. 1, pp. 117-142, 2018.

[3] Z. Masamalo, Persistent Dropout in Rural Community Secondary Schools in Tanzania : a Case of Makete District. Unpublished Master of Arts in Education Thesis: Mzumbe University, 2017.

[4] K. Ibrahim, "Influence of School Based Policies on Internal Efficiency in Public Day Secondary Schools in Nyatike Sub County, Kenya," Am. J. Educ. Res., vol. 6, no. 3, pp. 161-169, 2018.

[5] UNESCO, Manual on Concepts, Definitions and Classifications: Secondary Education (ISCED 2 and 3). 2019.

[6] B. Fleisch, J. Gultig, S. Allais, and F. Maringe, "Curriculum Reform, Assessment and National Qualifications Frameworks for the Future.," Backgr. Pap. Second. Educ. Africa, vol. 1, no. 2, pp. 1-93, 2019.

[7] C. Lopez, "Health, Education and Children's Rights: A comparability analysis of Kenya and Brazil," Heal. Phys. Educ. Commons J., vol. 1, no. 1, pp. 62-74, 2016.

[8] A. Riswanto and S. Aryani, "Learning Motivation and Student Achievement: Description Analysis and Relationships," Int. J. Couns. Educ., vol. 2, no. 1, p. 42, 2017.

[9] M. B. Kathy-Ann, The Educational Aspirations Of Barbadian Adolescent Mothers And Their Perceptions Of Support. Unpublished Thesis: Walden University, 2018.

[10]N. M. Njoroge, "Influence of Competitive Strategies on Performance of Rusinga Schools in Nairobi, Kenya," Int. J. Educ. Soc. Sci., vol. 1, no. 2, pp. 11-18, 2018.

[11] P. W. Ndirangu and J. A. Orodho, "Co-Curricular Activities: Are they Determinants of Holistic Education of Students in Secondary Schools in Kiambu and Samburu Counties, Kenya?," Greener J. Educ. Res., vol. 8, no. 3, pp. 055-064, 2018.

[12] R. Chebii, S. W. Wachanga, and Z. O. Anditi, "Effects of Cooperative E-Learning Approach on Students' Chemistry Achievement in Koibatek Sub-County, Kenya," Creat. Educ., vol. 09 , no. 12, pp. 1872-1880, 2018.

[13] J. Scoresby, M. Tkatchov, E. Hugus, and H. Marshall, "Applying Service Design in Competency - Based Curriculum Development," J. Competency-Based Educ., vol. 2, no. 7, pp. 1-13, 2018.

[14] J. M. Katamei and G. A. Omwono, "Intervention Strategies to Improve Students' Academic Performance in Public Secondary Schools in Arid and Semi-Arid Lands in Kenya," Int. J. Soc. Sci. Stud., vol. 3, no. 4, pp. 107-120, 2015.

[15]D. C. Manalang, P. Liongson, and E. N. T. Bayubay, The Lived Experiences of College Student Mothers in Managing their Dual Roles : An Exploratory Study. 2016.

[16] J. Wangui, M. Macharia, and D. K. Kessio, "Investigation of Re-Entry of Student Mothers in Secondary Schools in Kenya," Int. J. Humanit. Soc. Sci. Educ., vol. 2, no. 12, pp. 46-50, 2015.

[17] B. a Mahaffey, G. Hungerford, and S. Sill, "College Student Mother Needs At Regional Campuses: An Exploratory Study," AURCO J., vol. 21, no. 2, pp. 105-115, 2015.

[18] World Health Organization, "Measuring sexual health: Conceptual and practical considerations," WHO/RHR, vol. 10, no. 1, pp. 1-18, 2019.

[19] C. Chemnjor, "Against All Odds : Student Parents in Public Universities in Kenya," Int. J. Humanit. Soc. Sci. Educ., vol. 2, no. 6, pp. 130-140, 2015.

[20]Z. B. Moghadam, M. O. Khiaban, M. Esmaeili, and M. Salsali, "Motherhood Challenges and Well-Being Along With the Studentship Role Among Iranian Women: A Qualitative Study," Int. J. Qual. Stud. Health Well-being, vol. 12 , no. 1, pp. 1-10, 2017.

[21] M. Thuo, E. Marima, and F. Gitahi, "Influence of Permissive Parenting on Sexual Behaviour of Adolescents in Secondary Schools in Nakuru East Subcounty, Kenya," Sch. J. Arts, Humanit. Soc. Sci., vol. 2, no. 8, pp. 1309-1317, 2018.

[22] S. Taukeni, "The Main Challenges Student Mothers Experience to Manage Their Dual Roles," Int. J. Adv. Psychol., vol. 3, no. 3, p. 94, 2014.

[23] C. O. Gospel-Tony, N. O. Ezinne, and U. O. A. Annabel, "Psychosocial Challenges of Student Nursing Mothers in Tertiary Institutions in Imo State, Nigeria," Asian J. Educ. Soc. Stud., vol. 2, no. 1, pp. 1-6, 2018.

[24] I. N. Onyeka, J. Miettola, A. L. Ilika, and T. Vaskilampi, "Unintended pregnancy and termination of studies among students in Anambra state, Nigeria: are secondary schools playing their part?," Afr. J. Reprod. Health, vol. 15, no. 2, pp. 109-15, 2017.

[25] T. M. (Benedictine U. Spilovoy, "Motherhood and the Pursuit of Higher Education: A Phenomenological Study of College Student Mothers Completing Online Bachelor's Degree Programs," J. Educ. Train. Stud., vol. 3, no. 8, pp. 44-53, 2016.

[26] R. Brooks, "Student-Parents And Higher Education: A Cross-National Comparison," J. Educ. Policy, vol. 27, no. 3, pp. 423-439, 2016.

[27]K. Esia-donkoh, "Child-rearing practices among student-mothers at University of Cape Coast, Ghana," Soc. 
Biol. Hum. Aff., vol. 1, no. 32, pp. 14-21, 2017.

[28]K. Esia-donkoh, "Child-Rearing Practices Among Student-Mothers at University of Cape Coast, Ghana," Soc. Biol. Hum. Aff., vol. 1, no. 32, pp. 14-21, 2017.

[29]E. Newlin and S. R. Hooper, "Return-to-School Protocols Following a Concussion," N. C. Med. J., vol. 76, no. 2, pp. 107-108, 2015.

[30] UK Department for Education, "The Equality Act 2010 and schools," 2015.

[31] E. M. Rathgeber, “Gender Barriers Faced by African Women in Graduate Programmes and Research in the Social Sciences," 2016.

[32] V. Wedekind and T. Milingo, "Time to Learn Second Chances for Girls: The Zambian Re-entry into School Policy," 2015.

[33] D. Ncube and T.. Mudau, “'Legalising the Illegal' Interrogating the Policy That Allows Pregnant School Girls To Go for Maternity Leave and Come Back To School. A Case of Selected Secondary Schools in Gwanda District.," Glob. J. Adv. Res., vol. 4, no. 2, pp. 67-78, 2017.

[34] Ministry of Education, "Republic of Kenya National School Health Strategy Implementation Plan,” 2015.

[35][35] National Women's Law Center, “Justice for Her. Justice for All.," Kenya Law Rev., vol. 1, no. 1, pp. 1-8, 2019.

[36] Health \& Education Advice \& Resource Team, "Helpdesk Report : Education for pregnant girls and young mothers," $J$. Educ. Policy Entrep. Res., vol. 1, no. 5, pp. 1-17, 2015.

[37] J. J. Kurgat, “Administrative Support Factors Influencing Re-Admission of Teenage Mothers in Secondary Schools in Kenya: A Case of Baringo County," J. Educ. Pract., vol. 7, no. 30, pp. 208-211, 2016.

[38] B. C. Kiptanui, J. N. Kindiki, and J. K. Lelan, "Impact of Teenage Motherhood on the Academic Performance in Public Primary Schools in Bungoma County, Kenya," Int. J. Educ. Adm. Policy Stud., vol. 7, no. 2, pp. 61-71, 2015.
[39] M. Mudenda and E. Mbewe, "An Evaluation of the Implementation of Re-entry Policy in Primary Schools : A Case of Ndola District, Zambia," Int. J. Multidiscip. Res. Dev., vol. 4, no. 7, pp. 509-517, 2017.

[40] J. Baa-Poku, Girls' Re-Entry into School after Pregnancy in the Ashiedu Keteke Sub-Metro District, Accra. Unpublished Thesis: University of Ghana, 2016.

[41] A. Shaik, "Lived Experiences of Teen-aged Maguindanaon Student Mothers in South Central Mindanao, Philippines," Int. J. Eng. Trends Technol., vol. 64, no. 2, pp. 64-65, 2018.

[42] A. M. Cabaguing, "Motherhood and 'Studenthood': The Lived Experiences of College Student Mothers in Samar State University," Int. Rev. Soc. Sci., vol. 5, no. 3, pp. 213 219, 2017.

[43] G. Ellis, You Must be Superworman! How Graduate Student Mothers Negotiate Conflicting Roles. Unpublished Thesis: Texas Woman's University, 2014.

[44]H. Chauke, The Challenges Experienced By Teenage Mothers In Secondary Schools: The Case Of Hlanganani South Circuit. Unpublished Thesis: Ubniversity of Limpopo, 2013.

[45] Ministry of Education, Ministry of Education Republic of Kenya A Policy Framework for Education. Nairobi: Government Printers, 2018.

[46]E. Walgwe, N. Termini, H. Birungi, and C.-C. Undie, "Kenya: Helping Adolescent Mothers Remain in School through Strengthened Implementation of School Re-Entry Policies," African Popul. Heal. Res. J., vol. 1, no. 11, pp. 1$5,2016$.

[47] G. K. Sidhu, P. K. Veloo, Y. Xiaoyang, and P. S. A. Singh, "Teachers' perspectives of school and family cooperation: A case study in China," Univers. J. Educ. Res., vol. 7, no. 10 D, pp. 66-71, 2019.

[48] Budiharjo, "Quality of family education and its effect on fulfilling child care rights: A national survey," Univers. $J$. Educ. Res., vol. 7, no. 10, pp. 2179-2186, 2019. 